\title{
Mbeki agrees to step back from AIDS debate
}

Michael Cherry, Cape Town

AIDS researchers in South Africa have cautiously welcomed reports that President Thabo Mbeki has told the national executive committee of the African National Congress (ANC) that he is withdrawing from the debate on the science of the relation between HIV and AIDS.

A party spokesman confirmed that the

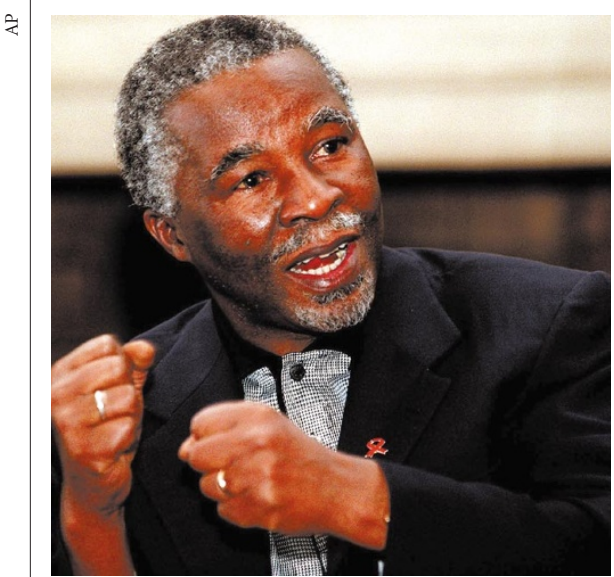

Mbeki: faces fears that his stand on HIV/AIDS has led to disillusionment with his leadership. cabinet has agreed that deputy president Jacob Zuma should chair a cabinet committee on the debate initiated by Mbeki on the link between HIV and AIDS, and the safety of antiretroviral drugs.

According to the Johannesburg Sunday Times, Mbeki has told the national executive committee - the party's highest-ranking decision-making body - that his participation in the debate was causing confusion. Party insiders reported concern in the government that the controversy was creating a negative mood in the country and had led to disillusionment with the president. It has also divided the ANC and its allies, the Congress of South African Trade Unions, and the South African Communist Party.

Mbeki apparently told the committee that he would leave his ministers, led by health minister Manto TshabalalaMsimang, to liaise with the international advisory panel that Mbeki set up to examine the HIV/AIDS issue. He also said that the committee of ministers, not him, would receive and process its report.

The report on the panel's deliberations has yet to be released, although it is said to have been submitted to the directors-general of health, and arts, culture, science and technology. But it has already met disapproval from both the dissident members of the panel, who regard it as unsupportive of their position, and the orthodox members, who feel it lacks a coherent synthesis of the debate.

A second report, put together by a taskforce appointed by the panel to investigate the reliability of HIV testing, should be ready by the end of the year, according to Tshabalala-Msimang. This will report on an experiment in which tests from each of South Africa's five testing centres for HIV will be repeated blind by the Centers for Disease Control and Prevention in Atlanta, Georgia, in an effort to confirm their reliability (see Nature 406, 113;2000).

There has been speculation among AIDS researchers that Mbeki's move may indicate a more pragmatic approach towards the issue. Last week Tshabalala-Msimang announced that HIV-positive pregnant women would be given the anti-HIV drug nevirapine at seven hospitals in KwaZuluNatal - the country's worst-affected province - in an expansion of the programme to investigate the prevention of mother-to-child infection.

\section{UK to make the northwest a post-genomics hotspot}

\section{David Adam, London}

The future of the Daresbury Laboratory in northwest England, home of the United Kingdom's current synchrotron light source, seems brighter. The centre is one of the biggest winners in a $£ 26$ million (US\$38 million) government package designed to enhance the region's science base.

The science minister Lord Sainsbury announced the funding during a visit to the laboratory just outside Manchester on Monday this week. Nine collaborative projects have secured government funding, most of them in genomics and imaging.

"These are areas in which the northwest excels," said Lord Sainsbury. As well as Daresbury, other projects involve researchers at universities and hospitals across the region.

Daresbury staff welcomed the investment, which many will see as a consolation prize after the government's decision to site the country's new synchrotron source, Diamond, at the Rutherford Appleton Laboratory near Oxford (see Nature 404, 323; 2000). Synchrotrons generate powerful X-rays used to determine the structure of biological molecules and advanced materials.

"The ground-level feeling around the place is that the awards are encouraging," says Tony Buckley, spokesman for Daresbury. "But there is also the feeling that this is very much a first course and that dinner is still to be served."

The largest chunk of money, $\mathfrak{E 9 . 8}$ million, will help to set up a post-genomics research consortium made up of four local teams, each involving the University of Manchester. Together with the University of

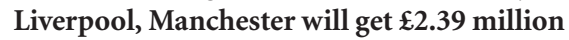
to combine physical and biological expertise in a Centre for Bioarray Innovation.

The University of Manchester Institute of Science and Technology joins these two

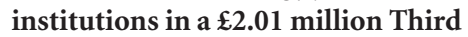
Generation Proteomics project to develop new ways of probing the protein-protein interactions at the root of many molecular diseases. And, together with Daresbury, the

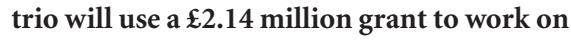
a Microfluidic Analytical and Screening Technology Centre.

This project sets out to develop highthroughput screening and genome-analysis techniques to support the region's healthcare and pharmaceutical industries. The University of Manchester will go it alone on the fourth post-genomics project: a clinically driven $\mathfrak{E} 3.0$ million investigation

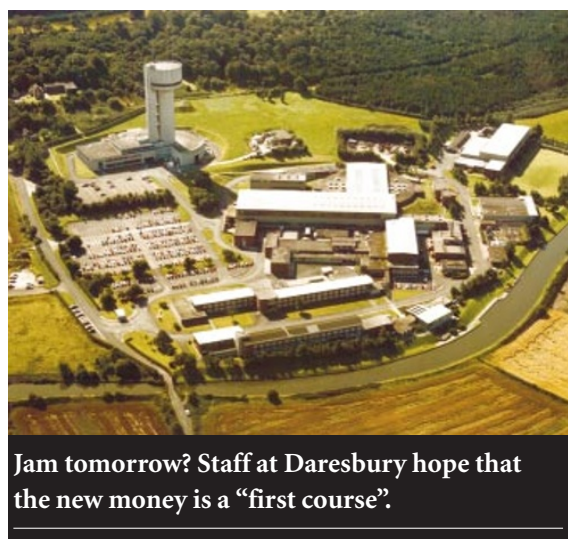

of how common diseases develop in individuals and populations.

Other projects include a $\mathfrak{E 2 . 6}$ million structural genomics centre to be built at Daresbury, and a $\mathfrak{E 5 . 7 5}$ million multidisciplinary Institute for Functional and Molecular Imaging that will develop and use diagnostic imaging and therapeutic techniques.

"This is great news for the northwest and recognizes the region's international standing in scientific research," said Sir Martin Harris, vice-chancellor of the University of Manchester and chairman of the North West Universities Association. 